International Journal of Trend in Scientific Research and Development (IJTSRD)

Conference Issue | March 2019 Available Online: www.ijtsrd.com e-ISSN: 2456 - 6470

Fostering Innovation, Integration and Inclusion Through

Interdisciplinary Practices in Management

\title{
A Meta-Analysis on Review of Studies on Water Management
}

\author{
Prof Anuradha Gaikwad1, Dr S. D. Kadam² \\ ${ }^{1}$ Assistant Professor, 2 Professor Head Environment Management \\ 1,2 chhatrapati Shahu Institute of Business Education and Research, Kolhapur, Maharashtra, India
}

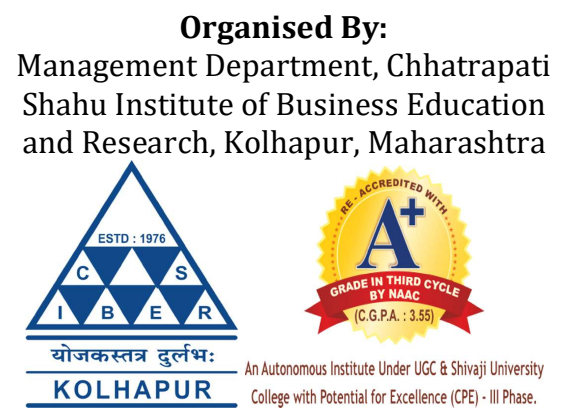

How to cite this paper: Prof Anuradha Gaikwad | Dr S. D. Kadam "A MetaAnalysis on Review of Studies on Water Management" Published in International Journal of Trend in Scientific Research and Development (ijtsrd), ISSN: 2456-6470, Special Issue| Fostering Innovation, Integration and Inclusion Through Interdisciplinary Practices in Management, March 2019, pp.121-125, URL: https://www.ijtsr d.com/papers/ijts rd23081.pdf

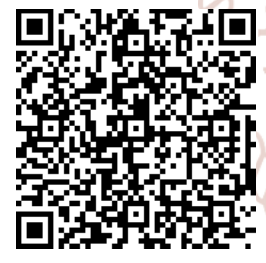
IJTSRD23081

\section{ABSTRACT}

Water is one of the most important resources available on this earth that has an influence on human activities. All important aspects such as agriculture, industry, day to day life is dependent on water. It is the most important factor for survival of life on this earth. As such it becomes imperative that we find out what is the status of various studies that have been conducted on various aspects of water management.

The present paper is an attempt to summarise various aspects of issues involved with use and consumption of water and studies involved therein. It focuses on theoretical concepts like definition of water management, compounding of water as well as actual practices of water management in various parts of the world.

\section{INTRODUCTION}

Water resource management is the activity of planning, developing and distribution system for managing the optimum use of water resources. World Bank has defined water resources management as development of surface and groundwater resources for urban, rural, agriculture, energy, mining, and industrial uses, as well as the protection of surface and groundwater sources, pollution control, watershed management, control of water weeds, and restoration of degraded ecosystems such as lakes and wetlands. This forms the basic element of their lending, supporting one of the essential building blocks for sustaining livelihoods and for social and economic development in general, (World Bank, Technical Note, 2003).

The World Bank document says that Integrated Water Resource Management as Integrated River Basin Management (IRBM) aims to establish a framework for coordination whereby all administrations and stakeholders involved in river basin planning and management can come together to develop an agreed set of policies and strategies such that a balanced and acceptable approach to land, water, and natural resource management can be achieved (World Bank, 2006). According to the Policy document (2012) on water of Government of India-Water resources development

and management will have to be planned for a hydrological unit such as drainage basin as a whole or for a sub-basin, multi-sect orally, taking into account surface and ground water for sustainable use incorporating quantity and quality aspects as well as environmental considerations. Environmental and ecological concerns are equally important and have to be addressed while managing water resources. Egemen and Aras (2009) have stated in their paper that as the demand of the society with respect to both ecological and chemical quality of Specific River stretches, its use and protection increases, it leads to new views and strategies towards policy for river basin management. Akpabio (2007) has reported that integrated water resources management involves the co-coordinated development, allocations, use and management of water, and related natural resources in order to meet present and future human needs whilst maintaining the functioning of vital ecological systems. Integrated Water Resources Management (IWRM) has been defined by the Global Water Partnership (GWP) as "a process which promotes the coordinated development and management of water, land and related resources, in order to maximize the resultant economic and social welfare in an equitable manner without compromising the sustainability of vital ecosystems" Over the last decades river basin management has become increasingly complex. Moreover, stronger, better and more efficient interlinked institutions will be required to handle the increased level of complexity (UN Jobs and Water 2016). 
International Journal of Trend in Scientific Research and Development (IJTSRD) @ www.ijtsrd.com eISSN: 2456-6470

The Sydney Catchment Authority - Catchment Management Report 2007-2008 basically talks about practices for catchment management. Information about following aspects is collected: extent of gully and soil erosion, extent, type and condition of land cover and use, condition of native vegetation, condition of riparian vegetation, extent and severity of wildfires and hazard reduction burns, biomass of potential fire fuel loads, extent of priority weed species.

In the past no such system or procedure is found in India to manage either water or land resources. Thus it becomes very difficult to scientifically evaluate the efficiency of water management in India.

The United Nations Department of Economic and social Affairs came out with Status Report on 'The Application of Integrated Approaches to Water Resources Management' on the issue of water management and this is what they have to say: 54\% of Very High Human Development Index (HDI) countries, $44 \%$ of medium and high HDI countries and $24 \%$ of low HDI countries reported high economic impacts from integrated approaches to water resources management (2002).

Gupta (2001) states in his article on Integrated Water Management that till very recently the Planning Process was dominated more by considerations of economic development. In 1996, the Working Group of the International Hydrological Program (IHP) of UNESCO defined sustainable management of water resources as "The management and use of water that supports society and its well-being into the indefinite future without degrading the integrity of the hydrological cycle or the ecological systems that depend on it".

The perceptions of what is required for sustainable water resources management and sustainability science in general have undergone major changes over the past decade. These are: An integrated approach expanding the scope of water protection to all waters, surface waters, and groundwater;

The hydrological principle where water management is based on river basins; The obligation to achieve a good status by 2015 ;

A "combined approach" of emission limit values and quality standards; Getting the prices right by introducing the principle of cost recovery; Getting citizens involved more closely by prescribing public participation in the development.

In India most of the systems of water management seem to be based on the Tennessee Valley Authority (TVA) approach of United States where the focus was more on compounding and distribution of water rather than sustainable water management (Tortajada, 2001) It is essential that the concept of sustainable water management is studied in totality so as to ensure water based livelihood for the further generations.

\section{Water footprint}

Traditionally the terms ground water and surface water have been used to denote water present in aquifers and rivers (also rivulets, streams, ponds) respectively. Of late two new concepts the green water and blue water have come into existence. Both surface water and ground water are denoted as blue water while water present in evapo transpiration cycle (water present in trees, crops and other vegetation) has been termed as green water (Taiekan Oki, et al, 2006). The water footprint of India is $987 \mathrm{~m} 3$ / cap / yr ie. A break up of the water footprint in terms of consumption of water shows that highly developed countries use more water for production of industrial goods while in a country like India $92 \%$ of water is used for consumption of agricultural goods (Hoekstra, Chapagain, (2007). Hence an understanding the concept of water footprint is essential to understand and analyse water consumption patterns of irrigation. Another fact is that increased water usage leads to increased economic growth (Hoekstra, 2004) and impacts the water footprint of a nation.

There is absence of literature that has calculated water footprint of various states or districts in India or studied this concept for regions in India.

\section{Environmental Flows}

The water policy briefing of International Institute of Water Management clearly spells the dangers of reduced environmental flows. Continuous water supply through appropriate adoption of management strategies that do not destroy the natural ecosystems and environment) should be developed (Laddo, 1997)

In the district of Kolhapur special types of weirs have been constructed on the river itself that regulate the flow of water. This has been responsible in altering the natural flow of water as well as impacted the movement of fish across the river. It has also resulted in increasing the intensity of pollution at periodic intervals due to artificial compounding of water.

The tenth plan gives an importance to "Regulating ground water use on a sustainable basis in order to avoid indiscriminate drawing of ground water will be a priority in the Tenth Plan, as overexploitation of ground water is causing various complications like sharp fall in the water table." The Report of the Working Group on Water Resources for the XI Five Year Plan (2007-12) - Government of India briefly discusses the pattern of development over the successive plan periods reflecting the gradual change from total thrust on construction of new projects in the early plan periods to completion of ongoing projects, command area development, renovation and modernization of the existing projects.

\section{Value of water}

Another important consideration is the value water has for all its stakeholders. According to UNESCO the value of water can change from case to case basis or on stakeholder perspective (Shatanawi, 2011). The business world and the industry are more associated with the monetary value of water while the society is more akin to day to day usage for their basic needs and recreational use. The Dublin principle established in1992 specifically states that water has an economic value and therefore should be acknowledged as an economic good (Rohani, 2013). Water has multiple uses. The cultural and social values are often in conflict with the economic values of water (Young, 2005) 
International Journal of Trend in Scientific Research and Development (IJTSRD) @ www.ijtsrd.com eISSN: 2456-6470

It is thus essential to find the value of water for people in any given region. This will help in finding out their opinions regarding value, usage and cost of water which are essential to come to conclusion about sustainable water management.

\section{Water and Economic Growth}

A document prepared for the HSBC by Frontier Economics explores the relationship between water and economic growth. Agriculture is responsible for $92 \%$ of the total water footprint in the world while drinking water and industrial usage accounts for the remaining $8 \%$ (Hoekstra et el, 2012). It is quite obvious that productivity of agriculture is dependent on water resources and an attempt has been made to find the relationship if any between the availability of water and the increase in economic indicators. As such effective management of water supply is a key element that should be incorporated into national employment Policy. Scarcity of water could negatively affect growth (Barbier, 2004). Proper utilisation of water can take place only through proper, holistic and sustainable management of water resources. India has a Seasonal Storage Index of 356.6 and GDP of 555 US dollars (Year 2003)In all industrial countries, the flows of almost all major rivers are regulated and managed, storing water for multiple uses, reducing peak flows, increasing low flows and protecting water quality, thus reducing the risk of water-related shocks and damage, increasing the reliability of water services for production, and reducing other negative impacts, such as disease (Gray 2006).Water and economic growth are linked to each other and as such scarcity of water would lead to lack of growth and development. The water management and water utilisation therefore needs to be studied. Water is a finite resource and one can only improve efficiency of yield using various techniques of irrigation but one can't per say increase the quantum of water. To ascertain the impact of water availability on life people the researcher has taken help of socio-economic indicators like literacy levels, number of children going to school, life expectancy levels, the income generated (EPW Research Foundation development indicators for India, 1994)

Thus though a lot of people have worked on the issue of water management, it is difficult to find work on the relationship between water availability and increase in socio economic indicators. Most of papers accessed for the literature review are non-Indian. One can find instances of work on water pollution, integrated river water management with respect to irrigation but not on socioeconomic impact of water availability. Whatever literature is available; is again for countries other than India. If we look at the GDP data we do find an increase in it. Economic indicators also show steady rise in per capita income of the district of Kolhapur. But a clear relation between the two should be documented. Thus an extensive research would be fulfilling a major gap with respect to planning for river water resource management. The relation between socio economic development and availability of water resources will also have to be established. An overall holistic approach towards water management would then emerge from the research study.

\section{References}

[1] Behera Deepak Kumar, (2016), Measuring SocioEconomic Progress In India: Issues And Challenges, Revista Galega de Economia Vol. 25-2
[2] Bruntland Commsion (1987), our Common Future

[3] Brown Casey and Lall UPmanu, (2006), Water and economic development: The role of variability and a framework for resilience, Natural resources Forum, 306 - 317 https://doi.org/10.1111/j.14778947.2006.00118.x

[4] Brown Casey, Meeks Robyn, Ghile Yonas, Hunu Kenneth, (2013), Phil. Trans. R. Soc. A 2013371 20120416; DOI: 10.1098/rsta.2012.0416. Published 30 September 2013

[5] Chaturvedi M. C. 1987. Water Resource Systems Planning and Management: Chapter 1 Introduction. Tata McGraw -Hill Publishing company Ltd: New Delhi.

[6] Davis Richard, Hirji Rafik (2003), Environmental Flows: Concepts and Methods Series Water Resources and Environment :Technical Note C.1 Environmental Flows: Concepts and Methods series editors

[7] Egemen, Togan Vedat, Berkun Mehmet. 2007. River water quality management model using genetic algorithm: Environ Fluid Mech, 439-50. Retrived 29th May, 2009 from Sringer Link database.

[8] Emmanuel M. Akpabio, Nigel M. Watson, Uwem E. Ite and Imoh E. Ukpong. 2007. Integrated Water Resources Management in the Cross River Basin, Nigeria: Water Resources Development, Vol. 23, No. 4, 691-708. Retrieved 29th May from INFLIBNET India Order.

[9] EPW Research Foundation. (1994). Special Statistics-8: Social Indicators of Development for India-II: InterState Disparities. Economic and Political Weekly, 29(21), 1300-1308. Retrieved from http://www.jstor.org/stable/4401238

[10] EPW Research Foundation. (1994). Special Statistics-7: Social Indicators of Development for India: I. Economic and Political Weekly, 29(20), 1227-1240. Retrieved from http://www.jstor.org/stable/4401207

[11] Fallenmark Malin (2013), Growing water scarcity in agriculture: future challenge to global water security, Phil. Trans. R. Soc. A 2013371 20120410; DOI: 10.1098/rsta.2012.0410. Published 30 September 2013

[12] Five year plan Report of the Working Group On Water Resources For the XI Five Year Plan (2007-12) Government of India

[13] Five year plan $10^{\text {th }}-$ Government of India

[14] Five year plan $11^{\text {th }}-$ Government of India

[15] Five year plan $12^{\text {th }}-$ Government of India

[16] Gupta, Rajiv K. (2001)'River Basin Management: A Case Study of Narmada Valley Development with Special Reference to the Sardar Sarovar Project in Gujarat, India', International Journal of Water Resources Development,17:1,55 - 78

[17] Gupta and Sharma,( 2010). Indian Journal of Agriculture Economics. Vol 65 No. 2 April June 2010 Dynamics of Land Utilisation, Land degradation and factors determining Land Utilisation in HP. 
International Journal of Trend in Scientific Research and Development (IJTSRD) @ www.ijtsrd.com eISSN: 2456-6470

[18] HSBC - Frontier Economics: Executive Summary, 2012, exploring the links between water and economic growth - A report.

[19] Hardin Garett The Tragedy of the Commons Science 162 (3859), 1243-1248 DOI: $10.1126 /$ science.162.3859.124

[20] Hoekstra AY, Mekonnen MM, Chapagain AK, Mathews RE, Richter BD (2012) Global Monthly Water Scarcity: Blue Water Footprints versus Blue Water Availability. PLOS ONE 7(2): e32688. https://doi.org/10.1371/journal.pone.003268

[21] Hoekstra, A. Y. and Mekonnen, M. M. (2011) Global water scarcity: monthly blue water footprint compared to blue water availability for the world's major river basins, Value of Water Research Report Series No. 53, UNESCO-IHE, Delft, the Netherlands.

[22] International Bank for Reconstruction and Development/ The World Bank (1995), Social Indicators of Development

[23] Kumar Rakesh, Singh R. D. and Sharma K. D. (2010), Water resources of India: National Institute of Hydrology, Roorkee 247 667, India. Current Science, Vol. 89, No. 5, 10 September 2005 accessed via internet. On $5^{\text {th }}$ sep 2010.

[24] Lado Cleophas (1997), Socio-economic factors influencing sustainable water supply in Botswana Author(s): Source: GeoJournal, Vol. 41, No. 1 (January 1997), pp. 43-53Published by: Springer Stable URL: http://www.jstor.org/stable/41147024. Accessed: 13/03/2014 07:01

[25] Maharashtra Government, (1989), Chapter 4, Maharashtra State Gazetteer Kolhapur District, published by Maharashtra Government.

[26] Maharashtra Pollution Control Board, (2004 - 2005), Chapter 9, Environmental Status Report Kolhapur Region, published by MPCB, pg 88

[27] Maharashtra Pollution Control Board, (2006), Chapter 6, White Paper on Pollution of River - Causes and Remedies published by MPCB, pg 305.

[28] Narayanmurthy A, (1997), Economic Viability of Drip Irrigation: An Empirical Analysis from Maharashtra, Indian Journal of Agricultural Economics; Bombay Vol. 52, Issue. 4

[29] National water Policy 2002 Government of India.

[30] Pahl- Wostl, MOstert C E, Tabara D. (2008), The growing importance of social learning in water resources management and sustainability science. Ecology and Society 13(1): 24. [online] URL: http://www.ecologyandsociety.org/vol13/iss1/art24/

[31] Rodriguez Martín, José Antonio, Holgado Molina, María Del Mar, Salinas Fernández, José Antonio, (2012), An Index of Social and Economic Development in the Community's Objective-1 Regions of Countries in Southern Europe, European Planning Studies, , Vol. 20 Issue 6, p1059-1074. 16p. 3 Charts 0965-4313; DOI: 10.1080/09654313.2012.673571, Accession Number: 76374208, Database: Entrepreneurial Studies Source
[32] Rohani M (2013), Freshwater Values Framework, A Review of Water Valuation Methods, Utilised Within Total Economic Valuation February 2013Working Report 2013/001

[33] Shatanawi M and Naber S , (2011), Dialogues on Mediterranean Water Challenges: Rational Water use, water price, water price versus value and lessons learned from the European Water Framework Directive, Valuing Water from Social , Economic and Environmental Perspective, pg 109 - 117.

[34] Shinde R. V. (1992) Studies on Hydrobiology of Panchaganga River System, Chapter $1 \&$ 6, Division of Environmental Biology, Department of Zoology, Shivaji University

[35] Singh Prasoon Kumar, Bhakat Dipanwita, Singh Gurdeep (2011) Assessment of Groundwater Resources of Panandhro Lignite Mining Region, Gujarat State, India, International Journal of Environmental Sciences Volume 1, No 7, 2011

[36] Skovlin Jon M. and Jain R. K. (1990), Range Management Stable, Source: Rangelands, Vol. 12, No. 5 (Oct., 1990), pp. 275-277Published by: Allen Press and Society for URL: http://www.jstor.org/stable/4000481Accessed: 06/09/2010 02:50.

[37] Society at a Glance (2009): The Organisation for Economic Co-operation and Development Social Indicators M2PressWIRE, Apr 26, 2010: Database: Newspaper Source Plus

[38] South Asia Network on Dams, Rivers and People (1999), River Basins Organisations in India Institutional Frameworks and Management Options. - A Case for Fundamental Review. November 99 issue.

[39] Stuart E. Bunn* \& Angela H. Arthington (2001), Basic Principles and Ecological Consequences of Altered Flow Regimes for Aquatic Biodiversity Cooperative Research Centre for Freshwater Ecology, Centre for Catchment and In-Stream Research Faculty of Environmental Sciences Griffith University Nathan, Queensland, Australia 4111

[40] Sukhpal Singh (2000) : Economic and Political Weekly, Vol. 35, No. 23 (Jun. 3-9, 2000), pp. 1886-1889, Published by: Economic and Political Weekly Stable URL: http://www.jstor.org/stable/4409348Accessed: 06/09/2010 02:57

[41] Sydney Catchment Authority (2008) Catchment Management Report 2007-2008

[42] Taikan OKI, et al, (2006) Global Hydrological Cyles and World Water Resources, cienc 313,1068, DOI 10.0026/Science. 1128845

[43] Tortajada Cecilia (2001), Institutions for Integrated River Basin Management in Latin America : Water Resources Development, Vol. 17, No. 3, 289-301, 2001

[44] UNEP 2012. The UN-Water Status Report on the Application of Integrated Approaches to Water Resources Management.

[45] United Nations Economic And Social Council,(1984) Chpater I -Definition, Selection And Use Of SocioEconomic Indicator 
International Journal of Trend in Scientific Research and Development (IJTSRD) @ www.ijtsrd.com eISSN: 2456-6470

http://repository.uneca.org/bitstream/handle/10855/ 14513/Bib-56066.pdf?sequence=1

[46] UNESCO, (1976) The use of socio-economic indicators in development planning, The Socio-economic indicators for development planning by M . V. S. Rao, UNESCO Press Paris 1976,

[47] WWAP (United Nations World Water Assessment Programme). 2016. The United Nations World Water Development Report 2016: Water and Jobs. Paris, UNESCO.

[48] "Water for Growth and Development." David Grey and Claudia W. Sadoff in Thematic Documents of the IV World Water Forum. Comision Nacional del Agua: Mexico City. 2006.

[49] World Bank (2006) Integrated River Basin Management Briefing Note 1, An Introduction to Integrated River Basin Management

[50] Yanni Gunnell., Comparative regional geography in India and West Africa: Soils, Landforms and Economic Theory in agricultural development strategies.

[51] Young Robert A (1931), Determining the Economic Value of Water: Concepts and Methods, Resources for the Future, USA.
[52] Zuo Qiting, Zhou KeFa, Xia Jun, Chen Xi \& Wang Yong Qin Xinjiang (2007), A quantified study method and its application to sustainable management of water resources in arid basins, Science in China Series D: Earth Sciences (C) 2007 Science In China Press Springer www.scichina.com www.springerlink.com Sci China Ser D-Earth Sci | June 2007 | vol. 50 | Supp. I | 9-15

[53] http://hdr.undp.org/en/content/human-developmentindex-hdi

[54] http://www.economicsonline.co.uk/Global_economics /Economic_development.html

[55] https://en.wikipedia.org/wiki/Economic_development

[56] http://shodhganga.inflibnet.ac.in/bitstream/10603/23 739/9/09_chapter_03.pdf

Copyright (C) 2019 by author(s) and International Journal of Trend in Scientific Research and Development Journal. This is an Open Access article distributed under the terms of the Creative Commons Attribution License (CC BY 4.0) (http://creativecommons.org/licenses /by/4.0)

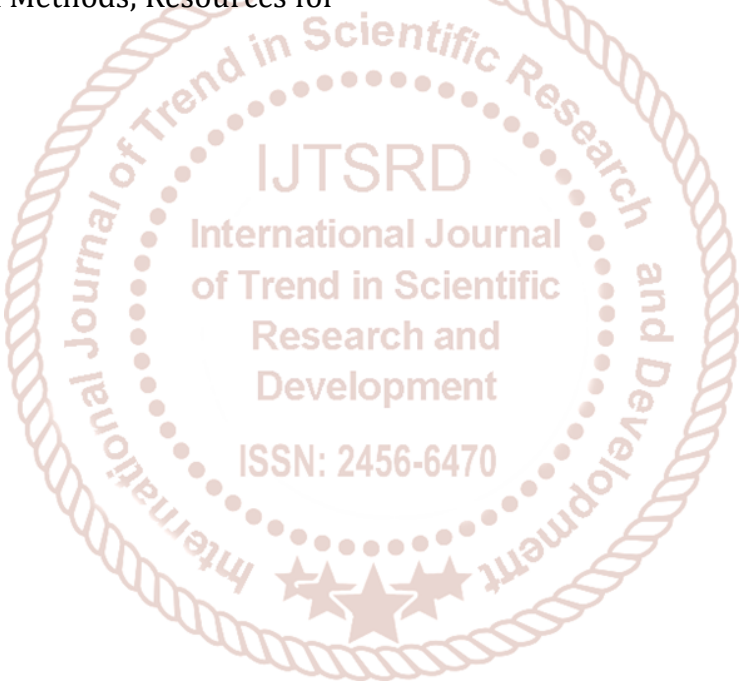

